\title{
Experimental Pneumonia Produced by Clinical Isolates of Pseudomonas cepacia in Mice
}

\author{
Yoshifumi YAMAGISHI, Jiro FUJITA, Keiichi TAKIGAWA, \\ Hiroshi MIYAWAKI and Jiro TAKAHARA
}

First Department of Internal Medicine, Kagawa Medical School

Ichiro YAMADORI

Department of Pathology, Kagawa Medical School

Kiyoshi NEGAYAMA

Clinical Laboratory, Kagawa Medical School

Kazuo FUJIMAKI

Research Laboratories, Toyama Chemical Co., Ltd.

Teruko NAKAZAWA

Department of Microbiology, Yamaguchi University

(Received: June 7, 1993)

(Accepted: July 9, 1993)

Key words: Pseudomonas cepacia, experimental pneumonia, mice

\begin{abstract}
An experimental Pseudomonas cepacia lung infection was induced in ddY mice pretreated with cyclophosphamide. A single dose of $250 \mathrm{mg}$ of cyclophosphamide per $\mathrm{kg}$ resulted in leukopenia which lasted for four days. At the lowest PMN levels, the mice were exposed to various doses of bacteria by either intratracheal inoculation or aerosol inhalation. Experimental pneumonia was established by intratracheal inoculation of $1 \times 10^{7}-2 \times 10^{8}$ colony-forming units of $P$. cepacia. The duration of survival time of the mice and the number of viable bacteria in their lungs were determined. A dramatic rise in the viable counts of $P$. cepacia was found within 24 hours after intratracheal inoculation of $1 \times 10^{8}$ colony-forming units of $P$. cepacia. It was impossible to establish $P$. cepacia pneumonia by aerosol inhalation, since the bacteria were immediately cleared from the lung. Mice which had not been treated with cyclophosphamide remained healthy and did not show any lung lesions. Thus, neutrophils appear to play an important role in the early defense mechanisms of the lung against $P$. cepacia. This animal model could be of use in evaluating additional therapies for the infection, and the pathologic determinants of infection caused by P. cepacia.
\end{abstract}

\section{Introduction}

Pseudomonas cepacia is an aerobic, glucose-nonfermenting gram-negative bacillus, that proliferates under conditions of minimal nutrition, and can survive even in the presence of certain disinfectants ${ }^{1,2}$. Over the past decade, this species has been increasingly recognized as a nosocomial pathogen ${ }^{2 \sim 77}$. The incidence of pulmonary colonization with $P$. cepacia has also increased in patients attending certain cystic fibrosis treatment centers and has been correlated with increased morbidity and mortality rates ${ }^{8 / 111}$. We recently reported the clinical features of $P$. cepacia pneumonia in immunocompromised patients for whom

\footnotetext{
別刷請求先：(勇761-07) 香川県木田郡三木町池戸

$1750-1$

香川医科大学第 1 内科藤田 次郎
} 
nebulizers were identified as the environmental reservoir for the epidemic strains ${ }^{12)}$. However, little is known about the biological behavior and pathologic determinants of $P$. cepacia in experimental animal infections ${ }^{13,14)}$. Therefore, the present study was designed to develop an experimental model to determine whether direct exposure of the respiratory tract to $P$. cepacia could lead to infection of either normal or immunosuppressed mice.

\section{Materials and Methods}

\section{Background}

Between January 1990 and August 1991, the respirafory tracts of 37 patients admitted to our Department of Internal Medicine with hematological malignancies or solid tumors were colonized by $P$. cepacia. Extensive surveillance cultures of the hospital environmental surfaces and respiratory equipment revealed that all nebulizing devices were contaminated with $P$. cepacia. Sixteen of these 37 patients developed pneumonia, and in 14 the pneumonia was considered to be due to $P$. cepacia ${ }^{12}$.

\section{Microorganism}

In this study, we used a clinically isolated strain of $P$. cepacia (KF-1). This strain produced protease and lipase, but not lecithinase and hemolysin, which was determined by plate assays as described previously ${ }^{15 / 18)}$. In the experiments described below, a stock culture was first transferred to a brain heart infusion agar slant (brain heart infusion [Difco], solidified by adding agar [Difco] to 1.5\%), and the slant was incubated overnight at $37^{\circ} \mathrm{C}$. Organisms from this culture were transferred to brain heart infusion broth, which was then incubated overnight at $37^{\circ} \mathrm{C}$. The cells in this broth culture were sedimented by centrifugation at $12,000 \times \mathrm{g}$ for $20 \mathrm{~min}$ and were then suspended in phosphate-buffered saline (PBS).

\section{Mice}

The mice were 4-weeks-old males of the ddY strain (Shizuoka Agricultural Cooperative Association for Laboratory Animals).

\section{Induction of experimental P. cepacia pneumonia}

The animals were bacterially challenged by intratracheal inoculation and aerosol inhalation.

\section{Intratracheal inoculation}

Mice were deeply anesthetized with ether and the ventral cervical region was cleaned with a $95 \%$ alcohol rub. A 0.2-inch medial longitudinal incision was then made to expose the trachea, and $0.05 \mathrm{ml}$ of washed suspensions of various concentrations of $P$. cepacia was placed in it. The incisions were allowed to heal naturally, and rapid closure was noted without evidence of infection.

\section{Aerosol inhalation}

The aerosol device used for the infection is illustrated in Fig. ${ }^{19}{ }^{19}$. Mice were placed in the exposure chamber $(50 \times 45 \mathrm{~cm})$ without restriction. The bacterial suspension, charged in a nebulizer (Vaponefrin Pocket Nebulizer, USV Pharmaceutical Co., Tuckahoe, N.J.), was aerosolized with compressed air. This aerosol was drawn through the exposure chamber then passed through five air-washing bottles connected to an aspirator. The first four air-washing bottles contained 4 liters of $70 \%$ methanol, and the fifth contained 4 liters of water. The atmospheric pressure in the exposure chamber was maintained slightly lower (1.3-cm water column) than that of the ambient pressure. At the end of nebulization, fresh air was introduced into the exposure chamber. When a bacterial suspension of $10^{9}$ colony-forming units (CFU) per $\mathrm{ml}$ was nebulized at an operating pressure of $1 \mathrm{~kg} / \mathrm{cm}^{2}$ for $40 \mathrm{~min}$, the maximal number of organisms in the chamber air, about $500 \mathrm{CFU} / \mathrm{ml}$, was reached $10 \mathrm{~min}$ after the beginning of nebulization, and this level was maintained. After the nebulizer was turned off, the number of bacteria in the chamber air declined rapidly, and after $30 \mathrm{~min}$, no bacteria were detected ${ }^{19}$. 


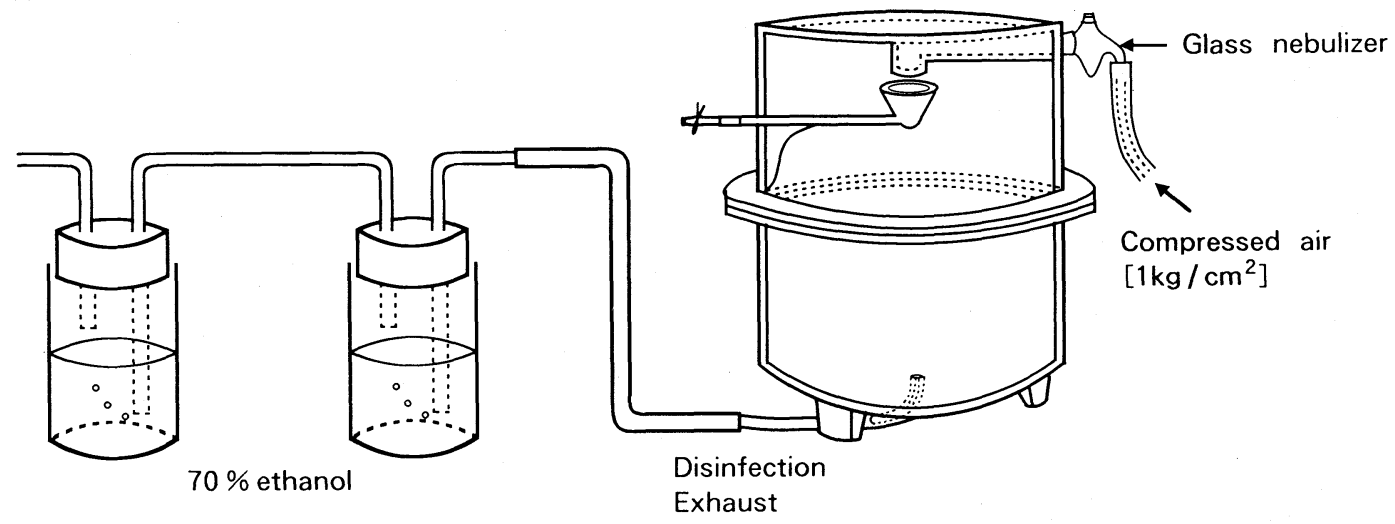

Fig. 1 Diagram of the aerosol exposure apparatus

Survival studies in leukopenia mice after challenge with P. cepacia aerosol

To determine the correlation between the mortality rate and the intensity of infection, groups (10 mice per group) of control and immunosuppressed animals were challenged by either intratracheal inoculation or aerosol inhalation of different numbers of bacterial $\left(5 \times 10^{6}-2 \times 10^{8} \mathrm{CFU} /\right.$ mouse $)$ on day 4 after cyclophosphamide treatment, and the survival rates were recorded.

Determination of $P$. cepacia clearance from the lung

The efficacy of the host's pulmonary defense mechanisms in clearing viable P. cepacia organisms from the lung was evaluated in mice treated with cyclophosphamide. These mice were challenged by an intratracheal inoculation of $1 \times 10^{8} \mathrm{CFU} /$ mouse or exposed to aerosols of a bacterial suspension containing $2.5 \times 10^{9} \mathrm{CFU} / \mathrm{ml}$. At various times after inoculation, groups of mice were exsanguinated by cardiac puncture under ether, the thoracic cavity was opened, and the lungs were aseptically removed. The lungs were weighed, then homogenized in $5 \mathrm{ml}$ of sterile PBS at $4^{\circ} \mathrm{C}$ with a Brinkman polytron (Brinkman Inst.). Serial 10 -fold dilutions were made from the homogenate, and $0.1-\mathrm{ml}$ quantities of selected dilutions were plated on Trypticase Soy Agar and incubated overnight at $37^{\circ} \mathrm{C}$. The following day colonies were counted, and the concentrations of $P$. cepacia in lung specimens were calculated as the total number of bacteria present in an entire lung and are described as the total bacterial count (TBC) per set of lungs. For convenience the $\mathrm{TBC}$ is expressed in logarithmic units to the base ten $\left(\log _{10} \mathrm{TBC}\right)$.

\section{Histopathological examination}

Groups of animals treated with cyclophosphamide were sacrificed 24 and $48 \mathrm{~h}$ after inoculation. Lungs were fixed in $7.5 \%$ formalin, embedded in paraplast, cut into 3- to $5-\mu \mathrm{m}$ thick sections, stained with hematoxylin and eosin, and examined under a light microscope.

\section{Results}

\section{Production of leukopenia in mice treated with cyclophosphamide}

Leukopenia was found in mice treated with a single intraperitoneal dose of $250 \mathrm{mg}$ of cyclophosphamide per $\mathrm{kg}$. Three days after applying the alkylating agent, the WBC counts had fallen from about $8 \times$ $10^{3} / \mu \mathrm{l}$ of blood to around $1 \times 10^{3}$ cells $/ \mu \mathrm{l}$ and persisted at this level until Day 4 . Recovery from the myelosuppressive effect started on Day 5, and a dramatic rise in WBC counts, indicating a strong rebound effect, was observed on Days 7 and 8. Peripheral PMN counts showed a similar profile of the WBC counts in their decline and recovery after cyclophosphamide treatment. They fell from around $9 \times 10^{2} \mathrm{cells} / \mu \mathrm{l}$ of blood to around $1 \times 10^{3}$ cells on Day 3 after treatment. PMN counts remained at this low level on Days 4 
A) CYCLOPHOSPHAMIDE (+)

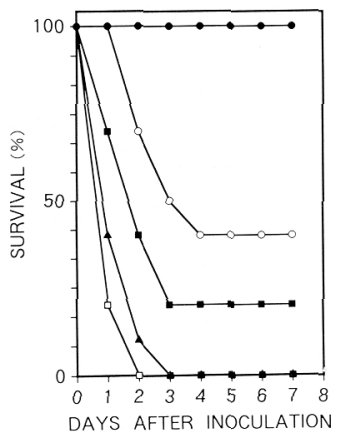

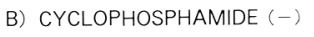

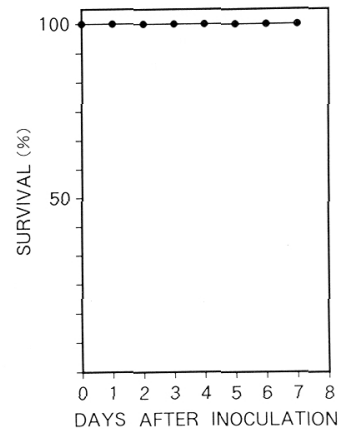

Fig. 2 Survival of mice after intratracheal inoculation of $P$. cepacia KF-1 (10 mice in each group). (A) Intratracheal inoculation of $2 \times 10^{8}(\square-\square), 1$ $\times 10^{8}(\boldsymbol{\Delta}-\mathbf{\Delta}), 5 \times 10^{7}(\mathbf{-}), 1 \times 10^{7}(\mathrm{O}-\mathrm{O})$, and $5 \times 10^{6}(-)$ P. cepacia. (B) Aerosol inhalation of $2 \times 10^{8}(-)$ P. cepacia.

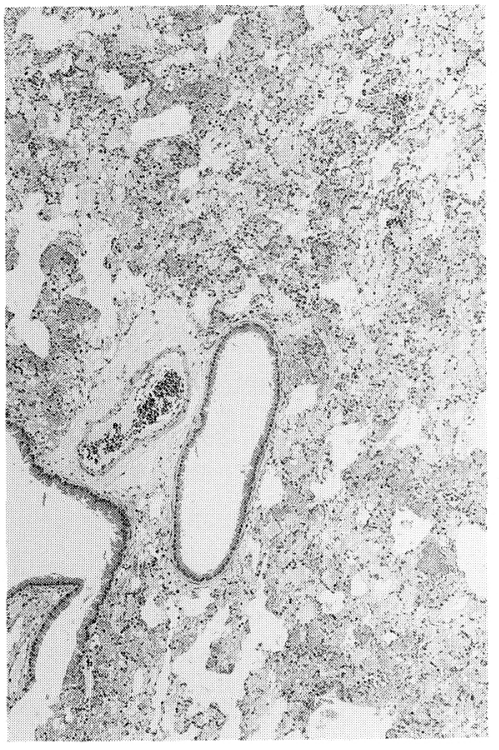

(A)
A) INOCULATION $\left(1 \times 10^{8} \mathrm{CFU} /\right.$ MOUSE) B) INHALATION $\left(2.5 \times 10^{9} \mathrm{CFU} / \mathrm{ML}\right.$
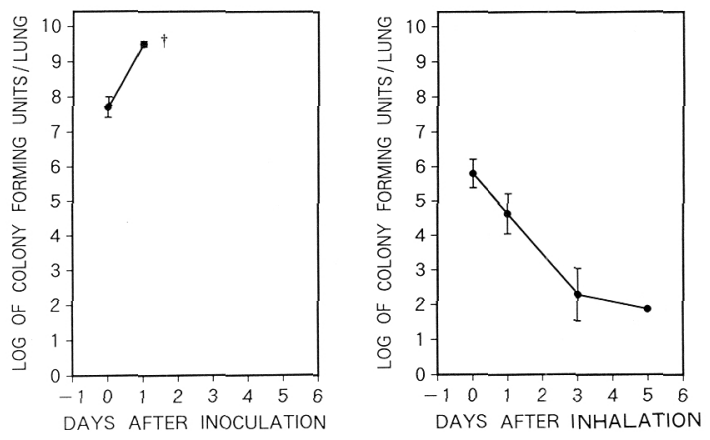

Fig. 3 Recovery of vialbe $P$. cepacia KF-1 from the lung tissues of mice.

(A) Intratracheal inoculation of $1 \times 10^{8} \mathrm{CFU} /$ mouse (mean $\pm \mathrm{SE}$ in 3 independent experiments). (B) Aerosol inhalation of $2.5 \times 10^{9}$ $\mathrm{CFU} / \mathrm{ml}$ (mean $\pm \mathrm{SE}$ in 3 independent experiments)

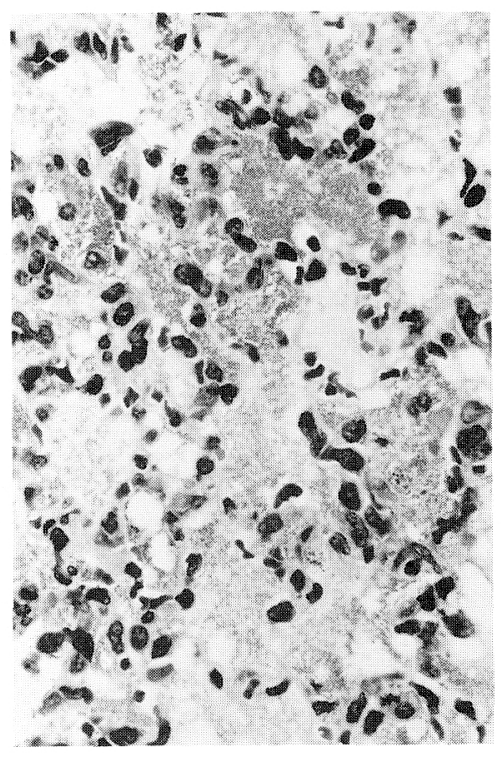

(B)

Fig. 4 Pathology

(A) Segmental units of the lung revealed pronounced proliferation of bacteria in edema fluid in alveolar sacs without marked infiltration by leukocytes $(\times 82.5)$. (B) Alveolar septa are infiltrated by small numbers of neutrophils and histiocytes, where proliferation of the bacilli is great $(\times 654)$

and 5. A dramatic increase of up to $1 \times 10^{4}$ cells/ $\mu 1$ was observed on Day 7 .

\section{Establishment of P. cepacia pneumonia}

Initially, it was impossible to establish P. cepacia pneumonia in normal mice by either intratracheal inoculation or aerosol inhalation. In addition, pneumonia could not be established even in WBC-depleted 
mice by aerosol inhalation even at the highest concentration of $P$. cepacia $\left(2.5 \times 10^{9} \mathrm{CFU} / \mathrm{ml}\right)$. P. cepacia pneumonia was established in only WBC-depleted mice by intratracheal inoculation.

Survival rate of mice after inoculation or inhalation with P. cepacia KF-1

All 10 immunosuppressed mice intratracheally inoculated with $2 \times 10^{8} \mathrm{CFU}$ of $P$. cepacia per mouse died within $48 \mathrm{~h}$. However, if the number of organisms was lower, the number of surviving animals and the survival time increased (Fig. 2A). In contrast, none of the non-immunosuppressed animals exposed to even $2 \times 10^{8} \mathrm{CFU}$ of $P$. cepacia aerosol per mouse showed any clinical signs, and all survived (Fig. 2B).

Recover of viable P. cepacia KF-1 from the lung tissue of mice

The means $\pm \mathrm{SE}$ of CFU of $P$. cepacia recovered from homogenized lung tissue at various times after inoculation are shown in Fig. 3. P. cepacia was usually isolated in pure culture. After an initial increase from about $6.0 \times 10^{7} \mathrm{CFU}$ inoculated per lung on Day 0 to about $3.3 \times 10^{9} \mathrm{CFU}$ per lung on Day 1, all the mice died (Fig. 3A). This was in contrast to the clearance of bacteria within a week when they were administered by aerosol inhalation (Fig. 3B).

Histology

Histological evaluation of hematoxylin and eosin-stained sections of mouse lung tissue is shown in Figure 4 . The lungs are generally edematous. Large numbers of bacilli are present in the alveolar space in units of segments with bronchioles in their centers. Segments with less bacterial proliferation tended to be have bacteria limited to alveolar spaces around the bronchioles. Infiltration of inflammatory cells is generally unremarkable despite the evident proliferation of bacilli in the alveolar space. However alveolar septa were infiltrated by small numbers of neutrophils and histiocytes, where proliferation of bacilli was greater.

\section{Discussion}

Many gram-negative bacteria, including $P$. cepacia, can multiply to very high levels in tap water, which is commonly used as a reservoir for inhalation therapy. The role of this organism in pulmonary disease remains controversial. Unlike Pseudomonas aeruginosa, $P$. cepacia is relatively nonvirulent, and it was not considered to be a primary human pathogen for many years because of its low degree of virulence and limited invasiveness. However, it has been implicated in a variety of respiratory tract infections, such as necrotizing and other forms of pneumonia ${ }^{20)}$, and lung abscesses ${ }^{21)}$. We previously described the clinical features of epidemic nosocomial $P$. cepacia pneumonia in immunocompromised patients ${ }^{12)}$. In our survey, pneumonia occurred in 16 of 37 colonized patients, of whom 14 were considered to be infected solely by $P$. cepacia. We attempted to establish experimental pneumonia with clinical isolates of $P$. cepacia in mice.

However, it was impossible to establish $P$. cepacia pneumonia by aerosol inhalation even in WBCdepleted mice. It was possible to deliver only $1 \times 10^{6} \mathrm{CFU} /$ lung even when $2.5 \times 10^{9} \mathrm{CFU} / \mathrm{ml}$ was inhaled, and these bacteria were immediately cleared from the lung. The determinants of lung clearance are multiple, including physical removal of bacteria, bacterial killing, and bacterial multiplication. It is generally believed that the decrease with time in the number of viable bacteria remaining in the lung after exposure to a bacterial aerosol is due both to physical removal of bacteria by the mucociliary system and to in situ bacterial killing. However, it should be considered that in humans, aerosols in the nebulizer are directly transported to the upper respiratory tract, and a relatively high concentration of bacteria could be delivered. In addition, in a clinical setting, when gram-negative bacilli are introduced by contaminated reservoir nebulizers through endotracheal tubes, or via tracheostomies, the mucociliary transport system is bypassed and large numbers of bacteria $\left(10^{7}\right.$ or more) may enter the lower respiratory tract.

In contrast, experimental pneumonia was established by intratracheal inoculation of WBC-depleted mice with $1 \times 10^{8} \mathrm{CFU} /$ mouse. Under these conditions, $6.0 \times 10^{7} \mathrm{CFU} / \mathrm{lung}$ was delivered. However, in 
normal mice these bacteria were cleared immediately and pneumonia could not be established, suggesting that $\mathrm{WBC}$ are closely related to the clearance of $P$. cepacia from the upper respiratory tract.

Relatively little is known about the virulence of $P$. cepacia ${ }^{23}$. Because the strains obtained from these patients produced protease and lipase, $P$. cepacia may damage the pulmonary tissue directly by releasing toxins and enzymes. In this study, lung infection by $P$. cepacia was restricted to immunosuppressed animals. Cyclophosphamide treatment predisposed these mice to vigorous proliferation of $P$. cepacia and probably more concomitant toxin production. Histologically there were numerous bacilli in the pulmonary alveoli, but inflammatory cell infiltration was weak, probably because of cyclophosphamide predisposition.

In addition, treatment of $P$. cepacia infection is complicated by the almost universal resistance of this organism to commonly used anti-pseudomonal agents ${ }^{24,25)}$. Therefore, this model may be useful in helping to establish effective prophylaxis against clinical isolates of $P$. сеpacia.

In conclusion, we believe that this experimental mouse model will be useful for evaluating the pathogenesis and treatment of $P$. cepacia pneumonia.

\section{References}

1) Dixon, R.E., Kaslow, R.A., Mackel, D.C., Fulkerson, C.C. \& Mallison, G.F.: Aqueous quaternary ammonium antiseptics and disinfectants: use and misuse. J.A.M.A. 236: 2415-2417, 1976.

2) Berkelman, R.L., Lewin, S., Allen, J.R., Anderson, R.L., Budnick, L.D., Shapiro, S., Friedman, S.M., Nicholas, P., Holzman, R.S. \& Haley, R.W.: Pseudobacteremia attributed to contamination of povidone-iodine with Pseudomonas cepacia. Ann. Intern. Med. 95: 32-36, 1981.

3) Sobel, J.D., Hashman, N., Reinherz, G. \& Merzbach, D.: Nosocomial Pseudomonas cepacia infection associated with chlorhexidine contamination. Am. J. Med. 73: 183-186, 1982.

4) Berkelman, R.L., Godley, J., Weber, J.A., Anderson, R.L., Lerner, A.M., Petersen, N.J. \& Allen, J.R.: The Investigative Team: Pseudomonas cepacia peritonitis associated with contamination of automatic peritoneal dialysis machines. Ann. Intern. Med. 96: 456-458, 1982.

5) Weinstein, R.A., Emori, T.G., Anderson, R.L. \& Stamm, W.E.: Pressure transducers as a source of bacteremia after open heart surgery. Report of an outbreak and guidelines for prevention. Chest 69: 338-343, 1976.

6) Steere, A.C., Tenney, J.H., Mackel, D.C., Snyder, M.J., Polakavetz, S., Dunne, M.E. \& Dixon, R.E.: Pseudomonas species bacteremia caused by contaminated normal and human serum albumin. J. Infect. Dis. 135: 729-735, 1977.

7) Centers for Disease Control. Pseudomonas cepacia colonization-Minnesota. M.M.W.R. 30: 610—611, 1981.

8) Isles, A., Maclusky, I., Corey, M., Gold, R., Prober, C., Fleming, P. \& Levinson, H.: Pseudomonas cepacia infection in cystic fibrosis: an emerging problem. J. Pediatr. 104: 206-210, 1984.

9) Thomassen, M.J., Demko, C.A., Klinger, J.D. \& Stern, R.C.: Pseudomonas cepacia colonization among patients with cystic fibrosis: a new opportunist. Am. Rev. Respir. Dis. 131: 791-796, 1985.

10) Tablan, O.C., Martone, W.J., Doershuk, C.F., Stern, R.C., Thomassen, M.J., Klinger, J.D., White, J.W., Carson, L.A. \& Jarvis, W.R.: Colonization of the respiratory tract with Pseudomonas cepacia in cystic fibrosis: risk factors and outcomes. Chest 91: 527-532, 1987.

11) Tablan, O.C., Chorba, T.L., Schidlow, D.V., WhiteJ.W., Hardy, K.A., Gilligan, P.H., Morgan, W.M., Carson, L.A., Martone, W.J., Jason, J.M. \& Jarvis, W.R.: Pseudomonas cepacia colonization in patients with cystic fibrosis: risk factors and clinical outcome. J. Pediatr. 107: 382-387, 1985.

12) Yamagishi, Y., Fujita, J., Takigawa, K., Negayama, K., Nakazawa, T. \& Takahara, J.: Clinical features of Pseudomonas cepacia pneumonia in an epidemic among immunocompromised patients. Chest 103: 1706-1709, 1993.

13) Starke, J.R., Edwards, M.S., Langston, C. \& Baker, C.J.: A mouse model of chronic pulmonary infection with Pseudomonas aeruginosa and Pseudomonas cepacia. Pediatr. Res. 22: 698-702, 1987.

14) Straus, D.C., Woods, D.E., Lonon, M.K. \& Garner, C.W.: The importance of extracellular antigens in Pseudomonas cepaciaa infections. J. Med. Microbiol. 26: 269-280, 1988.

15) Esselmann, M.T. \& Liu, P.V.: Lecithinase production by gramnegative bacteria. J. Bacteriol. 81: 939-945, 1961.

16) Sierra, G.: A simple method for the detection of lipolytic activity of microorganisms and some observations on the influence of the contact between cells and fatty substrates. Antonie van Leeuwenhoek J. Microbiol. Serol. 23: 15-22, 1957.

17) Sokol, P.A., Ohman, D.E. \& Iglewski, B.H.: A more sensitive plate assay for detection of protease production by 
Pseudomonas aeruginosa. J. Clin. Microbiol. 9: 538-540, 1979.

18) Vasil, M.L., Krieg, D.P., Kuhns, J.S., Ogel, J.W., Shortridge, V.D., Ostroff, R.M. \& Vasil, A.I.: Molecular analysis of hemolytic and phospholipase C activities of Pseudomonas cepacia. Infect. immun. 58: 4020-4029, 1990.

19) Nishi, T. \& Tsuchiya, K.: Experimental respiratory tract infection with Klebsiella pneumoniae DT-S in mice: chemotherapy with kanamycin. Antimicrob. Agents Chemother. 17: 494-505,1980.

20) Poe, R.H., Marcus, H.R. \& Emerson, G.L.: Lung abscess due to Pseudomonas cepacia. Am. Rev. Respir. Dis. 115: 861-865, 1977.

21) Dailey, R.H. \& Benner, E.J.: Necrotizing pneumonitis due to the Pseudomonad "Eugonic Oxidizer-Group 1". N. Engl. J. Med. 279: 361-362, 1968.

22) Jay, S.J., Johanson, W.G., Pierce, A.K. \& Reich, J.S.: Determinants of lung bacterial clearance in normal mice. J. Clin. Invest. 57: 811-817, 1976.

23) Stover, G.B., Drake, D.R. \& Montie,T.C.: Virulence of different Pseudomonas species in a burned mouse model: tissue colonization by Pseudomonas cepacia. Infect. Immun. 41: 1099-1104, 1983.

24) Gold, R., Jin, E., Levison, H., Isles, A. \& Fleming, P.C.: Ceftazidime alone and in combination in patients with cystic fibrosis: lack of efficacy in treatment of severe respiratory infections caused by Pseudomonas cepacia. J. Antimicrob. Chemother. 12A: 331-336, 1983.

25) Prince, A.: Antibiotic resistance of Pseudomonas species. J. Pediatr. 108: 830-834, 1986.

\section{マウスにおけるPseudomonas cepacia 肺炎モデルの作成}

香川医科大学第 1 内科
山岸 善文 藤田 次郎 瀧川 圭一
宮脇
裕史 高原 二郎
香川医科大学病理部
山 鳥 一 郎
香川医科大学附属病院検查部
根ケ山 清
富山化学研究所
藤 巻 一 雄
山口大学医学部微生物学教室
中 澤 晶 子

\section{要旨}

Pseudomonas cepacia (P. cepacia) 臨床分離株 の病原性を明らかにするためマウスに打ける $P$. cepacia 肺炎モデルの作成を試みた. $4-5$ 週齢の ddy 系雄マウスにP. cepacia 臨床分離株を経気管 投与，または噴霧吸入投与を行い，肺炎を若起し らるか否かを検討した. Cyclophosphamide (250 $\mathrm{mg} / \mathrm{kg}$ i.p.) 投与後の白血球減少マウスに扣いて は, P. cepacia $1 \times 10^{8} \mathrm{CFU} /$ マウス以上を経気管投 与することにより, マウスは全例死亡した。病理
組織像で細気管支周团を中心とした肺胞腔内に菌 や白血球の浸潤が認められ, 肺炎の存在が確認し えた。一方，P. cepacia の噴霧吸入投与では $2.5 \times$ $10^{\circ} \mathrm{CFU} / \mathrm{ml}$ 濃度の菌液投与でもマウスは全例生 存し, 肺炎を惹起しえなかった。白血球正常マウ スでは経気管投与, 噴霧吸入投与とも肺炎を作成 することはできなかった。この肺炎モデルは，P. cepacia の病原性因子の解析, 治療の選択に関して 有用な情報をもたはしうると考えられた。 